\title{
Solving Water Problems of a Metropolis
}

\author{
Ahmet Mete Saatci \\ Turkish Water Institute (SUEN), Istanbul, Turkey \\ Email: ahmet.saatci@suen.gov.tr
}

Received February 12, 2013; revised March 13, 2013; accepted March 27, 2013

Copyright (C) 2013 Ahmet Mete Saatci. This is an open access article distributed under the Creative Commons Attribution License, which permits unrestricted use, distribution, and reproduction in any medium, provided the original work is properly cited.

\begin{abstract}
The metropolis of Istanbul has faced water supply challenges throughout history; however the situation escalated in the past decade with rapid population growth. Water demand of an ever-growing city could only be solved by transporting water from surrounding water basins as far as $190 \mathrm{~km}$ away from the city border. Moreover, imbalanced distribution of water resources and imbalanced water demand on the European and Asian side of the city was resolved by transporting water from Asian side to the European side, by laying water transmission pipes under the Bosphorus Strait and by constructing a tunnel passing $130 \mathrm{~m}$ under the Strait. Another difficulty that required challenging solutions was the protection of water reservoirs of the city, hence illegal settlements arose in the reservoir watershed zones due to fast urban growth and migration from rural areas. Discharge of wastewater from illegal settlements caused not only algae growth in water treatment plant (WTP) of one of the largest reservoirs of Istanbul, but also eventual death of algae was a major setback due to anaerobic conditions created in the reservoir. The problem was solved by tertiary treatment of the wastewater and by diverting the effluent through a tunnel away from the reservoir. The aim of this paper is to provide an insight into setbacks faced in a metropolis of 14 million and technical solutions provided against the pollution of reservoirs.
\end{abstract}

Keywords: Eutrophication; Urban Growth; Water Resources; Water Shortage; Wastewater Treatment

\section{A Short History of Water Supply}

Istanbul is a metropolis with a population of nearly 14 million (greater than some European countries: Belgium, Portugal, Hungary, Greece, Czech Republic, 11 million; Sweden, Austria, 9 million; Bulgaria, Switzerland, 7.5 million; Denmark, Finland, Norway and Slovenia, 5.5 million) [1]. Moreover, its population increases every year exponentially and nowadays one fifth of Turkey's population lives in Istanbul (Figure 1).

Supplying water to Istanbul has been a problem throughout history. During the Byzantine period, Emperor Hadrian (117 - 138) brought water from locations close to the castle walls. Emperor Valens (364 - 378) constructed two aqueducts to bring water to the city. The water of the ancient city was stored in big underground reservoirs [2]. During the Ottoman Empire, 16 waterways totaling $130 \mathrm{~km}$ and 33 aqueducts supplied water to a population of $150,000-200,000$ people [3].

In 1882, French private water company started to work on supplying water to Istanbul from Terkos reservoir under the name "Dersaadet Water Company". In 1933 the company was nationalized and the Istanbul Water and Sewerage Administration (ISKI) was established [4].
Today, ISKI supplies $2,770,000 \mathrm{~m}^{3}$ of drinking water daily to the city. The water is treated in different water treatment plants located on the Asian and the European sides of the city. Advanced water treatment techniques including ozonation and powdered activated carbon are applied in the treatment plants.

During 1993 Istanbul lived through a severe drought [5]. Water could be supplied to residences only one day in a week and as a result, each apartment had their own water reservoir system to cope with the water shortages.

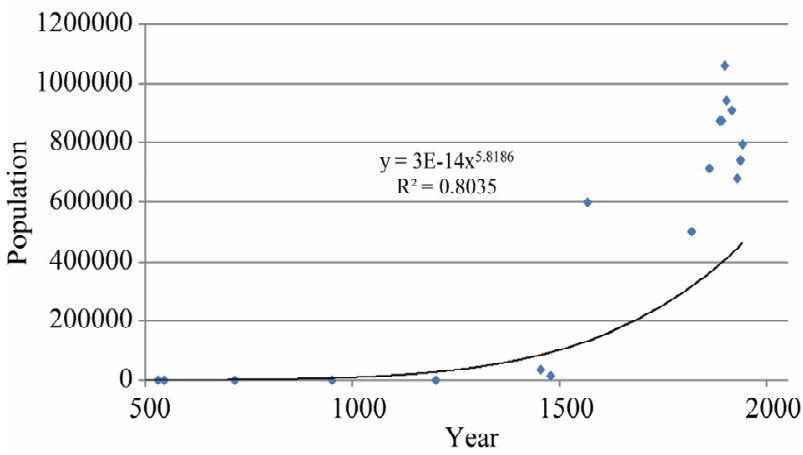

Figure 1. Past population growth of Istanbul. 
The water shortage problem lasted till 1994. The new ISKI Administration started by reducing the water unaccounted for by replacing the old water distribution system. $97 \%$ of water transmission lines were replaced reducing the unaccounted percentage from $65 \%$ to $27 \%$ [3]. Old polluted reservoirs such as Elmali (capacity: 15 million $\mathrm{m}^{3}$ ) was put into service and the water treatment plants were rehabilitated [6]. New water resources were searched and water was brought from creeks close to the Bulgarian border. The new Yesilcay reservoir system was put into operation. However, even such measures were not enough to supply water to a city of approximately 8 million in 1994 [7].

\section{Water Supply from a Basin $190 \mathrm{~km}$ Away}

An ambitious project was launched to bring water from Melen River which is $187 \mathrm{~km}$ east of Istanbul using a $2500 \mathrm{~mm}$ pipeline (Figure 2). The aim was to meet the city's forecast demands until the year of 2040 which will be around 3 million $\mathrm{m}^{3} / \mathrm{d}$ to meet the estimated future population (Figure 3 ).

The project with a total capacity of 1.180 million $\mathrm{m}^{3} /$ day will be carried out in three stages [9]. The first phase of the Project was completed in 2012 and 268 million $\mathrm{m}^{3}$ of water is now being supplied to the city [3]. This first phase cost 1.18 million dollars, for which two credit packages were obtained from Japan having a total value of 900 million dollars. 1.117 billion $\mathrm{m}^{3} /$ year water will be supplied at the end of the third stage.

The second stage involves the construction of Melen Dam. Additional pumping stations and water treatment plants will be installed and the second pipeline will be laid. In the final stage, new pumping stations, water treatment plants and the construction of the third pipe line will be completed [9].

\section{Crossing the Continents with a Water Tunnel}

About $60 \%$ of the water in Istanbul is on the Asian side. However, $60 \%$ of the population lives on the European side of the city [11]. To convey water from Asian side to European side, a $6 \mathrm{~m}$ diameter tunnel was constructed. The $5551 \mathrm{~m}$ long tunnel goes $135 \mathrm{~m}$ below the sea level crossing the two continents with a capacity to transfer 3 million $\mathrm{m}^{3}$ of water daily $[9,12]$. Water transferred from Melen River will be treated in Cumhuriyet Water Treatment Plant and will be pumped to Kagithane Water Distribution Center which is on the European side, using the water tunnel that crosses the Bosphorus [9]. The first phase of Cumhuriyet WTP has a capacity of 720,000 $\mathrm{m}^{3} /$ day and it is already constructed [13]. The total capacity of the Cumhuriyet WTPs will be $3,120,000$ $\mathrm{m}^{3} /$ day [14].

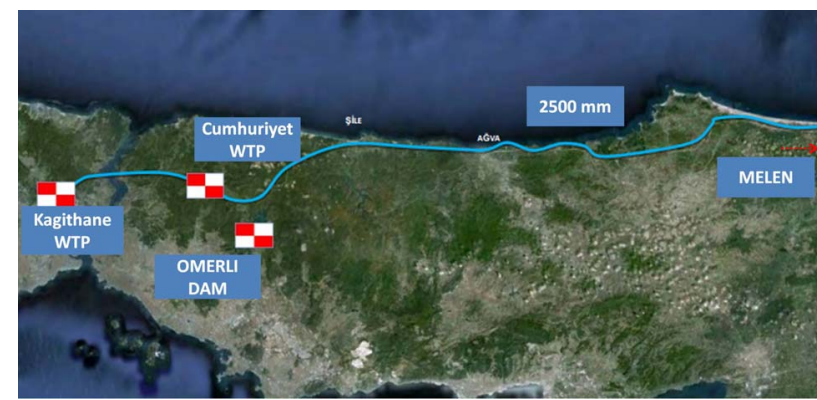

Figure 2. Layout of Melen project [10].

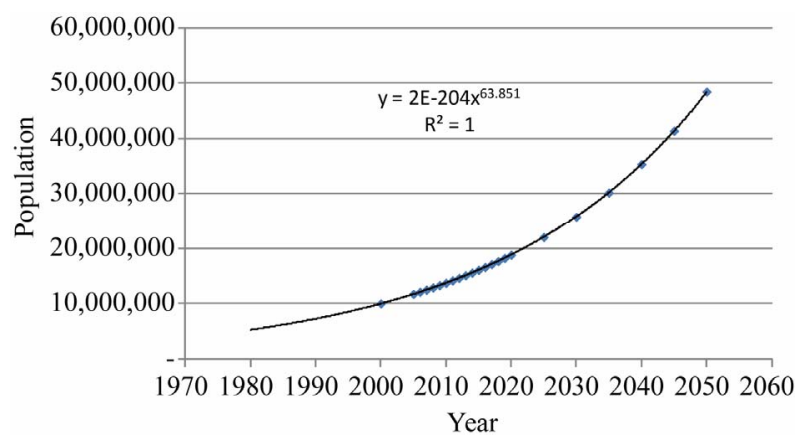

Figure 3. Future population of Istanbul [8].

\section{Saving Main Water Reservoir from Eutrophication}

One of the social problems of Istanbul is migration and as a result, this situation brings along illegal settlement complications. According to the ISKI Drinking Water Basins Regulations, watersheds are protected under four protection zones as shown in Figure 4 [15]:

Absolute Protection Zone (0 - 300 m): Any settlements, agricultural or mining activities are not permitted. Motor vehicles and the use of fertilizers and pesticides are not allowed. Afforestation is encouraged.

Proximate Protection Zone (300 - 1000 m): Industrial activities are not allowed. Permission can be given to residences with a population density of 5 persons/ hectare. The remaining area is subject to afforestation.

Mediate Protection Zone (1000 - 2000 m): Residences in $5000 \mathrm{~m}^{2}$ area or bigger than this parcel can be built with a density of 10 persons/hectare. However, construction of touristic facilities, industry, hospital or warehouses is prohibited. In addition, use of any chemical fertilizers and pesticides is also forbidden.

Remote Protection Zone (2000 m-basin boundary): Residences are allowed with a density of 20 persons/ hectare in a parcel with an area of $2500 \mathrm{~m}^{2}$ or bigger than this area. Construction of hospitals, chemistry laboratories, and medical faculties is not allowed. Moreover, stone, sand, clay, coal and mining activities are forbidden.

Although settlements around drinking water reservoirs 


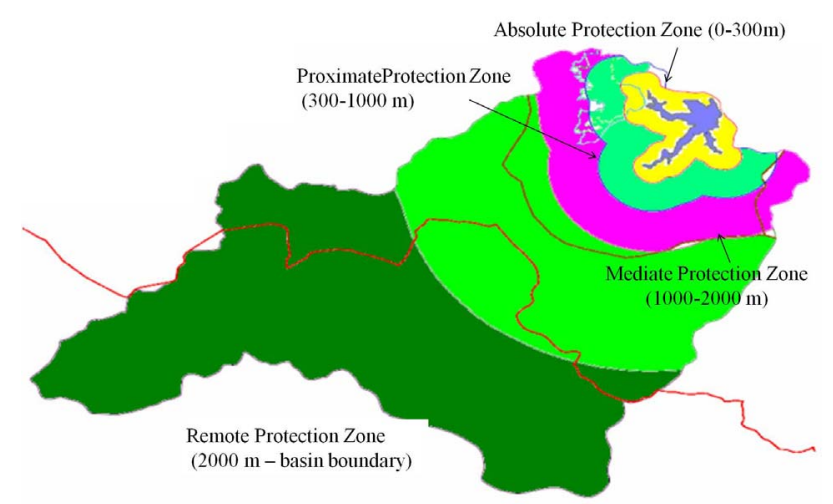

Figure 4. Watershed protection zones [16].

are prohibited according to regulations, squatters occupy vast areas within watershed zones and their wastewater generates a significant threat to the city's water supplies. In fact, Omerli Reservoir, which has a capacity of 387 million $\mathrm{m}^{3}$, was polluted by shanty towns that started to grow on its watershed zone in 1990s (Figure 5). These shanty towns (Sultanbeyli, Sarigazi, Yenidogan, Sultanciftligi and Alemdag) started to discharge their wastewater into creeks that joined the Omerli Reservoir. Eventually, the pollution load increased. BOD values increased from $110 \mathrm{mg} / \mathrm{L}$ to $300 \mathrm{mg} / \mathrm{L}$.

As a result of excess nutrients, the reservoir started to reach eutrophication stage hampering the water treatment process. The water started to smell and the algae clogged the deep bed filters. Powdered activated carbon was used to solve the odor problem. Filters were frequently backwashed leading to waste of backwash water and energy. Consequently, the first Pasakoy Wastewater Treatment Plant (WWTP) with a capacity of $100,000 \mathrm{~m}^{3} / \mathrm{d}$ was constructed in the shortest time possible to treat the wastewater reaching the reservoir. The plant was designed to remove phosphorous, carbon and nitrogen biologically. The aeration tank volume was designed to obtain stable sludge. After approximately one year of operation, algae growth could be stopped.

Water intake of the treatment plant was also used as a part of the treatment process by taking water from different levels. For about a year the floating algae could be protected by taking water from the bottom layers.

However, due to the settling of decaying algae at the bottom of the reservoir, dissolved oxygen (DO) levels at the bottom layer of the reservoir dropped down significantly causing the formation of an anaerobic bottom layer. In the absence of oxygen, iron and manganese in the bottom sludge dissolved into the drinking water supply. Iron and manganese were oxidized during the final chlorination and were adsorbed inside the main distribution pipes. Abrupt changes in the transmission line pressures caused the adsorbed iron and manganese deposits to detach. Subsequently, "red water" problem started and

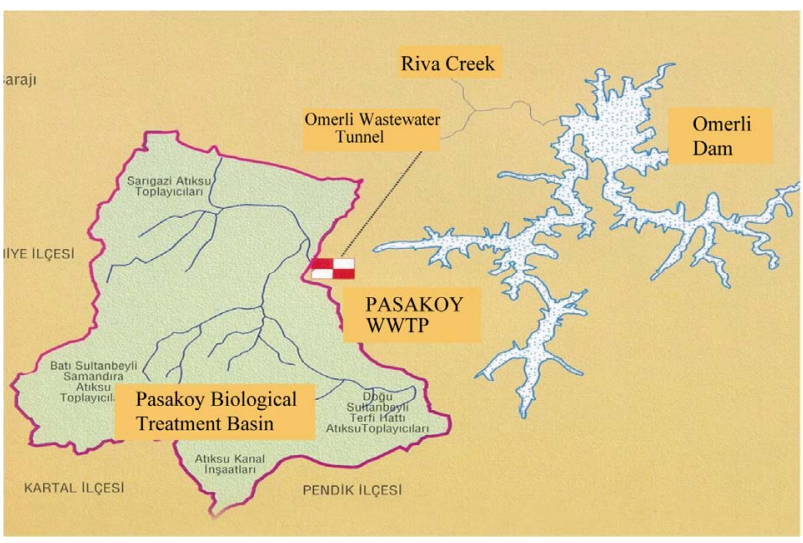

Figure 5. Omerli reservoir [17].

this problem could be solved after full operation of the Pasakoy WWTP.

As the first stage of the treatment plant reached its design capacity, the second new treatment plant was constructed and the effluent water is filtered and disinfected using UV disinfection units. The effluent is discharged to the Riva Creek and is used for irrigation.

\section{Conclusion}

As city population increases with population growth and migration, there will be a rise in water demand. Especially, the risk of spread of illegal settlements within the watershed zones should not be underestimated.

Istanbul sets a good example to the challenges faced in water supply in heavily populated cities, where illegal settlements on watershed zones pose a threat to scarce water resources. The pollution of Omerli Reservoir could be avoided by the implementation of a wastewater treatment plant in the shortest time possible. In addition, immediate action was needed to be taken against algae growth and algae death in the reservoir. Even then, all of these precautions were not enough to supply the demand of 14 million, until a massive water transfer project (Melen Project) has been started. Problems caused by lack of implementation of regulations could be compensated by engineering solutions.

\section{REFERENCES}

[1] TUIK-Turkish Statistical Institution, "Population Projections," 2013.

http://www.tuik.gov.tr/PreHaberBultenleri.do?id=15844

[2] ISKI-Iastanbul Water and Sewarage Administration, "Water Management in Istanbul throughout History," 2013.

http://www.iski.gov.tr/Web/statik.aspx?KID=1001112

[3] V. Eroglu, "Istanbul—Water Civilization," 2013. http://www.veyseleroglu.com.tr/belge/su_meselesi.pdf

[4] ISKI, “Tarih Boyunca Istanbul Sulari ve Istanbul Su ve 
Kanalizasyon Sorunlari,” 1983.

[5] DSI-State Haydraulic Works, "Press Release," 2008. http://www2.dsi.gov.tr/basinbul/detay.cfm?BultenID=144

[6] ISKI, "ISKI Annual Report 2011,” 2012.

http://www.iski.gov.tr/Web/UserFiles/File/faaliyetraporu 2008/faaliyetraporu2011.pdf

[7] DIE-State Statistical Institution, "Turkish Population, 1923-1994) Demographics and Development," 1995. http://kutuphane.tuik.gov.tr/pdf/0013683.pdf

[8] DIE, "Nüfus Sayım1," 2000.

http://bianet.org/bianet/bianet/96034-istanbul-2023te-21milyon-2050de-50-milyon

[9] DSI, "XIVst Regional Directorate of State Hydraulic Works-Istanbul," 2013. http://www2.dsi.gov.tr/english/region/14st.htm

[10] M. Aygun, "Protection of Melen Water and Basin," 2012. http://www.inbo-news.org/IMG/pdf/4_MEHMET_AYG UN_EUROPEINBO2012 MELEN_SUYU_VE_HAVZA SININ_KORUNMASI.pdf

[11] WaterWiki, "Facing Water Challenges in Istanbul," 2013. http://waterwiki.net/index.php/Facing_Water_Challenges in_Istanbul
[12] STFA, "Melen Project," 2012.

http://www.facebook.com/media/set/?set=a.45707953430 3306.110027.139193936091869\&type $=3$

[13] Beykoz Municipality, "First Phase is open at Melen," 2013.

http://www.beykoz.bel.tr/icerik/29/1277/istanbulun-sigort asi-melende-1-kisim-acildi--.aspx

[14] Limak, "Istanbul Cumhuriyet Drinking Water Treatment Plant," 2013.

http://www.limak.com.tr/sectors/construction/projects/dri nking-waters-and-treatment-facilities/istanbul-cumhuriyet -drinking-water-treatment-plant

[15] A. Akkoyunlu, E. Yuksel, F. Erturk and H. Bayhan, "Managing of Watersheds of Istanbul (Turkey)," Fifth Water Information Summit: Regional Perspectives on Water Information Management Systems, Florida, 23-25 October 2002.

[16] G. Erul, "Su Kirliliği Kontrolü Yönetmeliği,” T.C. Çevre ve Şehircilik Bakanlığ (Ministry of Environment and Urbanization), 2013.

[17] ISKI, “Ömerli İçmesuyu Havzasi Koruma Sistemi,” 2013. http://www.iski.gov.tr/web/haberDetay.aspx?HID=10040 74 